International Journal of Geography and Geography Education (IGGE)

To Cite This Article: Başdoğan Deniz, G. \& Enlil, Z. Ş. (2021). The importance of cultural economy in regional development policies: TRB2 region and Van city. International Journal of Geography and Geography Education (IGGE), 44, 235-252.

\title{
THE IMPORTANCE OF CULTURAL ECONOMY IN REGIONAL DEVELOPMENT POLICIES: TRB2 REGION AND VAN CITY ${ }^{1}$
}

\author{
Bölgesel Kalkınma Politikalarında Kültür Ekonomisinin Önemi: TRB2 Bölgesi ve Van Kenti
}

Gülçinay BAŞDOĞAN DENiZ²

Zeynep Şirin ENLIL ${ }^{3}$

\begin{abstract}
Öz
Çalışmada TRB2 Bölgesi ve Van İlinin kalkınma sorununa kültür ekonomisi ekseninden bakılmaya çalışılmıştır. Buna göre; bölgesel aktörlerden ulusal düzeyde Doğu Anadolu Kalkınma Ajansı (DAKA), uluslararası düzeyde Avrupa Birliği (AB)'nin TRB2 bölgesine ve Van iline sağlanan mali destek ve hibe programları; aktörlerin kendi kurumsal sınıflaması, tüm ekonomik faaliyetlerin uluslararası standart sektör sınıflaması, kültür ekonomisi sınıflaması ve beşeri kalkınma endeksine göre sınıflandırılarak yatırımlar/destekler/hibeler kültürel yatırım ve beşeri boyutta değerlendirilmiştir. Araştırmada 2004-2015 yılları arasındaki dönemde etkin aktörlerin; TRB2 Bölgesi ve Van kentinin kalkınmasına etkileri, TRB2 Bölgesi ve Van kentinin kalkınmasında hangi sektörlere öncelik verdikleri, TRB2 Bölgesi ve Van kentine biçtiği roller, kendi kurumsal sınıflaması ile kültür ekonomisi ve beşeri kalkınma endeksi sınıflamaları arasındaki benzerlik ve farklılıkların neler olduğu belirlenmeye çalışılmıştır. Sonuç olarak Avrupa Birliği (AB) bölgesel kalkınma politikaları çerçevesinde sosyal ve beşeri kalkınmaya yönelik yatırımlara öncelik vermiştir. Doğu Anadolu Kalkınma Ajansı (DAKA) ise, farklı sektörleri içeren bir büyüme modeli yaklaşımını benimsemiştir.
\end{abstract}

Anahtar Kelimeler: Kültür Ekonomisi, Kültür Politikaları, Bölgesel Kalkınma, Avrupa Birliği (AB) ve Doğu Anadolu Kalkınma Ajansı (DAKA), TRB2 Bölgesi, Türkiye

\begin{abstract}
In this study, the development problem of TRB2 Region and Van City is tried to be examined from the cultural economy. Accordingly, the financial support and grant schemes provided by the regional actors The Eastern Anatolia Development Agency (EADA) at the national level and the European Union (EU) at the international level to the TRB2 region and Van City were examined. Investments/subsidies/grants have been assessed on cultural investment and human scale. These were evaluated by the actors' own corporate classification, the international standard sector classification of all economic activities, cultural economy classification and human development index. In the research, the effects of active actors on the development of TRB2 Region and Van City in the period between 2004-2015, which sectors they gave priority in the development of TRB2 Region and Van City, the roles they assigned to TRB2 Region and Van City, the similarities and differences between their own institutional classification and the cultural economy and human development index classifications are aimed to be determined. As a result, the European Union (EU) has given priority to investments in social and human development within the framework of regional development policies. The Eastern Anatolia Development Agency (EADA), on the other hand, has adopted a growth model approach that includes different sectors.
\end{abstract}

Keywords: Cultural Economy, Cultural Policies, Regional Development, European Union (EU) and Eastern Anatolia Development Agency (EADA), TRB2 Region, Turkey

\footnotetext{
${ }^{1}$ This research is derived from corresponding author's doctoral thesis entitled: "Analysis of Culture Oriented Investments in the Development Policies and Investments of Turkey: City of Van Case in terms of European Union, Central and Local Government Investments.

${ }^{2}$ Correspondence to: Assist. Prof., İskenderun Technical University, Faculty of Architecture, Department of City and Regional Planning, İskenderun, Hatay, TURKEY., https://orcid.org/0000-0003-3281-911X., gulcinay.basdogan@iste.edu.tr

3 Prof., Yıldız Technical University, Faculty of Architecture, Department of Urban and Regional Planning, Beşiktaş, i̇stanbul, TURKEY., https://orcid.org/0000-0002-6328-7665., enlil@yildiz.edu.tr
} 


\section{INTRODUCTION}

Since the end of the twentieth century, the value and importance of cultural activities have been increasing economically, nationally and internationally. Culture, which is an effective structure for social, economic and spatial transformation, stands out in academic studies in terms of the role of creative industries on economic development. Although the effects of cultural sectors on economic life are mostly evident in developed countries, this effect has started to manifest itself in developing countries as well. In addition to providing employment primarily in the framework of cultural policies established for the purpose of growth/improvement/development, the cultural economy is also an important driving force in the preservation, survival and sustainability of cultural values.

Cultural economy is defined as all economic activities carried out by the public or private sector towards cultural heritage, creative arts and cultural industries and is associated with the behaviors of producers, consumers and the state in the cultural industry (United Nations, 2010). This broad description encompasses a variety of industrial sectors, artistic mediums, and cultural products. The cultural economy that developed in response to the economic, social and political changes that started in the 1980s caused governments to develop urban cultural policies (Bianchini, 1993; Grodach and Silver, 2012; Grodach and Seman, 2013). The progress of cultural strategies depicts that initial concentration was on improving tourism and culture and on embellishing the city's perception via the development of grand designs, iconic cultural projects, and centres of attraction (Grodach and Seman, 2013; Mommaas, 2004; Zukin, 1996).

Cultural policies have gained importance in urban development policies due to the fact that culture constitutes an economic structure and is used as a tool in the reorganization of urban space. The concept of development which has changed in the world after the middle of the 20th century has turned into a structure that takes human capital into consideration. With this structure, the economic structure (cultural economy) based on technology, information, creativity and culture has started to be implemented in cities through culture-based urban strategies. During this process in Turkey, together with the change of the development concept after 1980 and the diversification of the actors giving direction to the development, it is seen that there are changes in the cultural perspective and that culture is instrumentalized by being used as an investment area, even if not directly but indirectly.

At this point, the research focuses on whether there is a relationship between the cultural economy and development policies in the investments of the international actor European Union (EU) and the regional actor Eastern Anatolia Development Agency (EADA) in the TRB2 Region, where regional inequality is the highest in Turkey. The research aims to assess the development problem of the Region through the cultural economy in accord with the investments of the actors.

The financial support and grant programs provided to the TRB2 region were evaluated with the content analysis method. Which actors direct regional development policies in TRB2 region, how do EADA and the EU view the development issues of TRB2 region, which / which of the projects supported by the EU and EADA are directly or indirectly related to culture and culture economy were aimed to be explained within the scope of the study. According to this study, the grants/supports/investments made to TRB2 and Van between 2004-2009 and 2009-2015 were categorized according to the institutional classification of actors, the international standard sector classification of all economic activities (ISIC REV.4 / NACE REV.2), cultural economy classification and human development index.

\section{LITERATURE REVIEW}

\section{Effects of Cultural Economy on Economic Development}

In economies focusing on economic development in order to improve welfare, cultural sectors should not be included in development policies (DiNoto and Merk, 1993). However, it is seen that modern economic approaches based on economic and cultural development and evaluating this structure as a whole are more effective in overcoming economic recession and crisis with appropriate cultural policies and alternative solution strategies (Cunningham et al., 2008).

Grodach (2013) mentions five basic models, emphasizing the different dimensions of the improvement and development of a value-added cultural economy. These models are; traditional, creative city, cultural industries, cultural professions and cultural planning models. When we look at these models and policies, it is seen that cultural economy models, which are different from traditional economic development model, are low-cost, information-arts and culture-oriented and emphasize social business networks and location quality. While the world economy contracted during the crisis of the 2000s, the commercial volume of products associated with the creative economy 
increased. The European Commission states that the creative and cultural sectors should be used to increase the global competitiveness of the region and emphasizes the impact of creativity on innovation and economic development/growth within the perspective of the Lisbon strategy (EC, 2007; EC, 2015).

The creative and cultural sectors increased by $12 \%$ faster than the overall economy in Europe with a turnover of 654 billion euros in 2003. It is estimated that this sector constitutes 3\% of the EU's GNP and provides jobs for nearly 6 million people (Cooke and De Propris, 2011). On a country-by-country basis, this contribution was up to $5 \%$ in the United Kingdom between 1997 and 2007, 3,5\% in Italy and 4,8\% in Spain in 2011 (Lazzeretti, 2013). This rate varies between 3-6\% in East Asian countries where technology-intensive creative concentration is observed (2000), and 2-3\% in Australia (2000-2005) and New Zealand (1996-2001) (Potts and Cunningham, 2008; Lazzeretti, 2013). In the United States (1997-2007), the sector's contribution is estimated to be over 4\%. It is stated that in China, Russia and African countries, creative and cultural sectors are under development (UNCTAD, 2008). When the developing countries are examined, it is seen that the concept of cultural economy is newly perceived and there is not sufficient information and infrastructure (Lazzeretti et al., 2014).

The Council of Europe has classified the economic effects of culture and art under two headings. The first is the direct economic impact of cultural industries in relation to value-added services in the field of media and telecommunications. The other includes indirect economic impacts that create social profitability and social credit for people and institutions (Gordon and Beilby-Orrin, 2007).

The creative industries that nurture the cultural economy have invested in many private and public institutions and have recently contributed to economic diversity based on high-quality cities and regions or re-industrialization (Montgomery, 1996; Pratt, 1997). People working in the creative industry earn income from developing and exporting different services and products, attracting artists, high-human capital artists and other firms with the efficiency of nonlocal cultural industries and the diversity of cultural assets. Creative industries, cultural expressions, communication technologies and creativity in material production combine commercial goods and services, as well as consumptionbased markets (Montgomery, 1996). Andersson (1985) stated that when cultural industries are emphasized as a pillar of regional development, many factors that can be regarded as negative in traditional sectors can be perceived as positive values. It is stated that concepts such as economic instability, imbalance, and uncertainty may be necessary to accelerate development by emphasizing the creative features at the local level. The cultural economy provides opportunities for many regions to generate employment and income. Thus, regions can create employment by marketing their cultural products through modern technologies (Kumral and Güçlü, 2013; Keser, 2016).

Garcia (2004) mentioned that the determination of development goals locally within the framework of cultural policy as a means of urban transformation is not perceived as a part of the whole and stated that it may have a negative impact on social welfare. Kong (2000), on the other hand, stated that it would be a wrong approach if cultural policies that have an impact on quality of life, social cohesion and social development are evaluated as absolute income and employment oriented.

Scott (2006), stated that local, national and international cultural strategies designed to integrate competitiveness and cooperation at regional and local scale would be more likely to achieve economic development goals.

Creative industries are expected to combat the injustices of social exclusion and economic development, as well as increase in GNP and employment. Some researchers stress that social development/growth is neglected due to the focus on unilateral economic development/growth. At this point, Evans and Shaw, (2004) stated that creative industries had a bourgeois effect on work and living spaces, while Leadbeater and Oakley (2001) explained that the problem of unregistered employment in related sectors increased economic inequalities. It is also stated that the role of creative industries in economic development is exaggerated and causes economic inequality, gentrification and instability of the local economy (Oakley, 2004).

\section{Actors in Regional Policy in Turkey, Cultural Policies in Regional Development Plans: EADA and EU}

Economic development constitutes the most obvious main objective of all countries. Economic and social activities, which mostly concentrate around a certain center in each country, have led to the emergence of inter-regional development disparities, leading to significant socio-economic problems (Arslan, 2005). At this point, there was a need for a regional policy aiming at eliminating the interregional differences by balancing the difference of regional development and bringing the underdeveloped regions closer to the social-economic-cultural structure in the developed regions. In line with this need, regional policies have gained importance in development policies and a new formation and understanding has been made based on planning and development policies. 
Analyzing the development policies of Turkey in national and regional scale is important in terms of determining the perspective from which the actors in the region evaluate the mentioned development problem. The role of the EU as an international actor in regional development policies should first be determined in order to evaluate the investments and the development policies and the investments in TRB2 region and Van City. The plans and strategies prepared within the framework of the development policies of EADA, the regional actor in the TRB2 region, were evaluated from the cultural perspective.

\section{Cultural Policies Under the National and Regional Development Policies in Turkey}

The evaluation of development policies at national and regional level in Turkey is of great importance in terms of interpreting the relationship between culture and development. Within this context, first of all, Turkey's national development policies were evaluated summarily and cultural policies in national development plans were examined.

\section{National Development Policies in Turkey}

Looking at the development policies pursued since 1923, two main strategies (one open to the outside, based on free trade principles, the second one based on protectionism and state intervention to achieve the goal of industrialization) have evolved. In the first years of the Republic, in 1923-29, in the open economy conditions, free foreign trade policy was applied firstly, and it was understood that this policy was inadequate due to the economic crisis in the world and in 1930-1939 a closed, protective and statist industrialization strategy was started to be implemented. These policies were interrupted due to the start of the Second World War, and the decision to limit imports was taken in 1953-1960 period ("new statism" policy, which symbolized a radical break with the 1930s statism), followed by the import substitution industrialization strategy (1963-1976). Since the import substitution industrialization strategy entered the economic crisis at the end of the 1970s, an export-based growth model started to be implemented since 1980 (Eşiyok, 2004). To summarize the policies pursued in this context; the 1923-1950 statutory period, the 1950-1976 import substitution period and the post-1980 liberal policies aimed at globalization and export-oriented growth model within the framework of EU harmonization (Yardımcıoğlu et al.,2012).

\section{Cultural Policies in the 1963-2023 Five-Year Development Plans}

In order to accelerate the economic and social development in Turkey, on September 30, 1960, with the law number 91, the State Planning Organization (SPO) was established. The organization, which was responsible for advising the government in determining the economic, social and cultural goals of the state, became the Ministry of Development in 2011. SPO in charge of advising the Government in determining economic, social, and cultural purposes turned into the Ministry of Development in 2011. The Ministry of Development nonetheless was transformed into the Presidency of the Republic of Turkey Presidency of Strategy and Budget from 2018 onwards. Since 1963, five-year development plans have been implemented. Eleven national development plans were prepared between 1963 and 2021. The objectives of the development plans prepared vary according to the economic and social conditions of the period.

The role of cultural policies in Turkey's development process during the period of the republic, took shape with national identity and revolutions. Starting with development plans in 1963, they have undergone several changes periodically. Accordingly, economic, social and cultural development was aimed between 1953 and 1967, but the scope of cultural development was not mentioned. It is aimed to develop, preserve and promote Turkish culture on the basis of national culture. In the period of 1968-1972, the importance of cultural activities as a human element in economic development is emphasized and it is stated that culture is a regulator of social life. National cultural policies in 1973-1977 were considered as the driving force in social and economic development. In the plans of the period before 1979-1983, while the culture was evaluated in social and economic integration, it was seen in the Fourth Development Plan that it was evaluated as a development problem in integrity with all institutional areas. It is stated that democratization will take place with the elimination of unbalanced distribution between regions in cultural services and the effectiveness of local administrations in cultural activities. In 1985-1989 periods, the concept of "National Culture" was emphasized. Encouragement system has been proposed for the protection of historical monuments and locality has been given importance with the development of handicrafts specific to the regions. Between 1990 and 1994, it was aimed to maintain national cultural policies, to provide support to private theaters, to prepare cultural activities of municipalities and thus to ensure the participation of local administrations in cultural activities. For the first time, copyright was mentioned and preparations for legal regulation were proposed. Cultural wealth was emphasized in 1996-2000, but it was underlined that cultural activities should not pose a threat to national integrity. Studies have been proposed for geographical signs specific to the locality and it is stated that historical and cultural monuments should be protected. In the 2001 and 2005 period, a special importance was given to the development and preservation of the Turkish 
language by shaping cultural policy over cultural values. Between 2007 and 2018, it was aimed to preserve the original structure of cultural identity and the common identity was emphasized. In this way, it is aimed that local administrations play an active role in the cultural policies of public and non-governmental organizations, to give importance to historical and cultural values in urban identity and to increase the contribution of cultural industries to the economy. In addition, for the first time the economic value of cultural industries was mentioned. Between 2019 and 2023, spreading cultural and artistic activities, increasing the multiplier effect of culture on development, reviving cultural heritage to cultural tourism, creating cultural awareness through written and visual media, developing projects sensitive to cultural identity in urban transformation projects, support mechanism for the creation of the culture industry and cultural entrepreneurship are aimed.

\section{EU as an International Actor in Regional Development Policies}

In 1999, with the adoption of Turkey's EU membership candidacy, Turkey's EU accession process strategy, plans and program began to take shape under the EU harmonization. The harmonization process is reflected in the national programs of Turkey as "Long- and Medium-Term Programs" with Accession Partnership Document (APD) and EU Progress Reports (YIImaz, 2012). In some of the EU's progress reports on Turkey's membership, it was emphasized that the necessary preparations should primarily be made in order to designate NUTS and establish Regional Development Agencies (Çalt, 2005). Especially in the 2003 Accession Partnership Document (APD), what needs to be done in Turkey regarding regionalization, has been identified. These include: the development of national development plans and regional development plans at Nomenclature of Territorial Units for Statistics (NUTS) ${ }^{1}$ level and the development of a national economic and social cohesion policy aimed at reducing regional disparities, adoption of a legal framework to facilitate the implementation of the EU Acquis, the establishment of multi-year budgeting procedures that set priority criteria for public investment in regions and strengthening the administrative structures that will lead the Regional Development (Accession Partnership Certificate, 2003). Accordingly, Turkey's first Preliminary National Development Plan (pNDP), was prepared within the framework of Turkey-EU relations to act as the basis for the use of pre-accession financial assistance for economic and social cohesion to be provided by the EU in 2004-2006. Accordingly, it was aimed to effectively use pre-accession financial assistance in the pNDP period and to establish the infrastructure for the use of structural funds after membership (ÖUKP, 2003). Within the concept of regional development, the pNDP divided Turkey in to specific Statistical Regional Unit (IBB) and identified three different levels. Accordingly, Turkey is divided into 26 IBB and level-2 regions (Ekiz and Somel, 2007). Accordingly, by the development agencies established in the level-2 regions established within the IBB, regional development was deemed possible and the development of the whole of Europe was aimed (Taş, 2006). Accordingly, the pNDP paved the way for planning at the regional level with the Statistical Regional Units.

Between the years 1999-2006 serious changes in the institutional structure of the EU harmonization process in Turkey has started to develop regional policies realized. In 1999, Turkey's EU acceptance of candidate membership and preaccession, with the start of negotiations in 2005, benefiting from the financial assistance and the scope of EU harmonization establishment Agencies Development in 2006, is considered a milestone in the regional development approach. Thus, the EU has been directly involved in development policies and institutional structure at international level.

The fact that the EU is an important actor in development policies and regional planning understanding and that it supports the TRB2 region with the support of MEDA program in the process of establishing development agencies, underlines the importance of this study. Regional development concept in Turkey, started with the Eastern Anatolia Project (DAP) Master Plan in 2000, has been shaped by the MEDA program in 2004 and has evolved into an institutional

\footnotetext{
${ }^{1}$ With the 2002/4720 numbered Council of Ministers Decision, the collection of regional statistics in 2002, making the socio-economic analysis, determining the framework of regional policy and in order to establish EU Regional Statistical System (Nomenclature of Territorial Units for Statistics NUTS) according to comparable data base Statistical at three different levels Regional Units in Turkey was created. According to this system, three regions correspond to 81 cities, neighboring cities constitute 26 level two regions and neighboring level two regions constitute 12 level one regions. These regions were analyzed under the headings: Human Capital and Employment, Income, Economic Structure, Entrepreneurship and Innovation, Social and Physical Infrastructure, Accessibility, Digital Life and Communication, Natural Structure, Environment and Climate Change, Energy, Corporate Structure and Social Capital, Settlement Pattern and Development Trends and Regions by Development and Income Status. Development status of regions were determined according to the 2011 Socio-Economic Development Index (SEGE) study, which was prepared by using 61 variables mostly from 2009-2010 under eight sub-categories: Demographic, Education, Health, Employment, Competitive and Innovative Capacity, Financial Capacity, Accessibility and Quality of Life. The Level 2 regions of the country are considered in four levels in terms of development levels. Classification of the regions of Turkey in terms of per capita income is as follows: Regions with higher than average Gross Value Added (GVA) per capita are defined as High Income. Regions below the average per capita GVA but above 75\% are defined as Medium-High Income. The regions which are below $75 \%$ and above $50 \%$ of GVA per capita average are defined as Medium-Low Income, regions below 50\% of GVA per capita average are defined as Low Income. Accordingly, Eastern Anatolia and Southern Anatolia Regions were included in the low-income class (Ministry of Development, 2014).
} 
structure with the establishment of EADA. In particular, the fact that the TRB2 region is the most underdeveloped region is important for EU regional policies.

\section{Eastern Anatolia Development Agency (EADA) and Regional Plans}

Within the scope of the research, Van was selected as the sampling area and was classified as Central Anatolia Region (TRB) as Level 1 and TRB2 (Van, Muş, Bitlis, Hakkari) as Level 2. According to the Socio-Economic Development Ranking Research of Provinces and Regions (SEGE-2017), in the fourth stage in terms of the level of development, per capita, GSKD value is defined as the lower of $50 \%$ of the average in Turkey "Low Income Level" takes place in the class. Bitlis and Van draw attention as the provinces, which benefit more from the incentive system, within the TRB2 Region (Republic of Turkey Ministry of Industry and Technology, 2019). Within the scope of the Socio-Economic Development Ranking Survey of the Provinces and Regions, the TRB2 region is in the fourth level in terms of development level. The TRB2 region takes place in the Low-Income Level class, which is defined as the regions with gross value added (GVA) value lower than $50 \%$ of the average in Turkey.

According to the TUIK data garnered in 2020, the employment rate is $36.4 \%$ in the TRB2 region, while $42.8 \%$ in Turkey. While the unemployment rate in the region TRB2 is $23.6 \%$, it is $13.2 \%$ in Turkey. Accordingly, TRB2 Region ranks penultimate among 26 regions in the unemployment rate. The employment rate is above the industry average of Turkey in the agricultural sector in the TRB2 region, whereas the employment rate in the services and industry sectors is below average (see table 1).

\begin{tabular}{|l|l|l|l|l|l|l|l|l|l|}
\hline \multicolumn{8}{|c|}{ Table 1: Turkey and TRB2 Regions Employment Rates by Sectors (TÜiK,2021) } \\
\hline YEAR & $\begin{array}{l}\text { REGION } \\
\text { CODE }\end{array}$ & REGION NAME & Total $\mathbf{( 1 , 0 0 0 )}$ & $\begin{array}{l}\text { Agriculture } \\
\mathbf{( 1 , 0 0 0 )}\end{array}$ & $\begin{array}{l}\text { Industry } \\
\mathbf{( 1 , 0 0 0 )}\end{array}$ & $\begin{array}{l}\text { Services } \\
\mathbf{( 1 , 0 0 0 )}\end{array}$ & Agriculture (\%) & Industry (\%) & Services (\%) \\
\hline 2020 & TR & Turkey & 26,812 & 4,716 & 7,036 & 15,060 & 17.6 & 26.2 & 56.2 \\
\hline 2020 & TRB2 & $\begin{array}{l}\text { Van, Muş, Bitlis, } \\
\text { Hakkari }\end{array}$ & 516 & 209 & 87 & 219 & 40.5 & 16.9 & 42.4 \\
\hline
\end{tabular}

Development Agencies were established with the Law No. 5449 dated 25.01.2006 named "The Law for the Establishment, Coordination and Duties of Development Agencies" (Official Gazette, 2006). There are 26 Development Agencies established in Turkey. Eastern Anatolia Development Agency (EADA) was established on 22 November 2008. EADA covers Bitlis, Muş, Hakkari and Van (TRB2) and continues its activities in Van as the center (see figure 1).

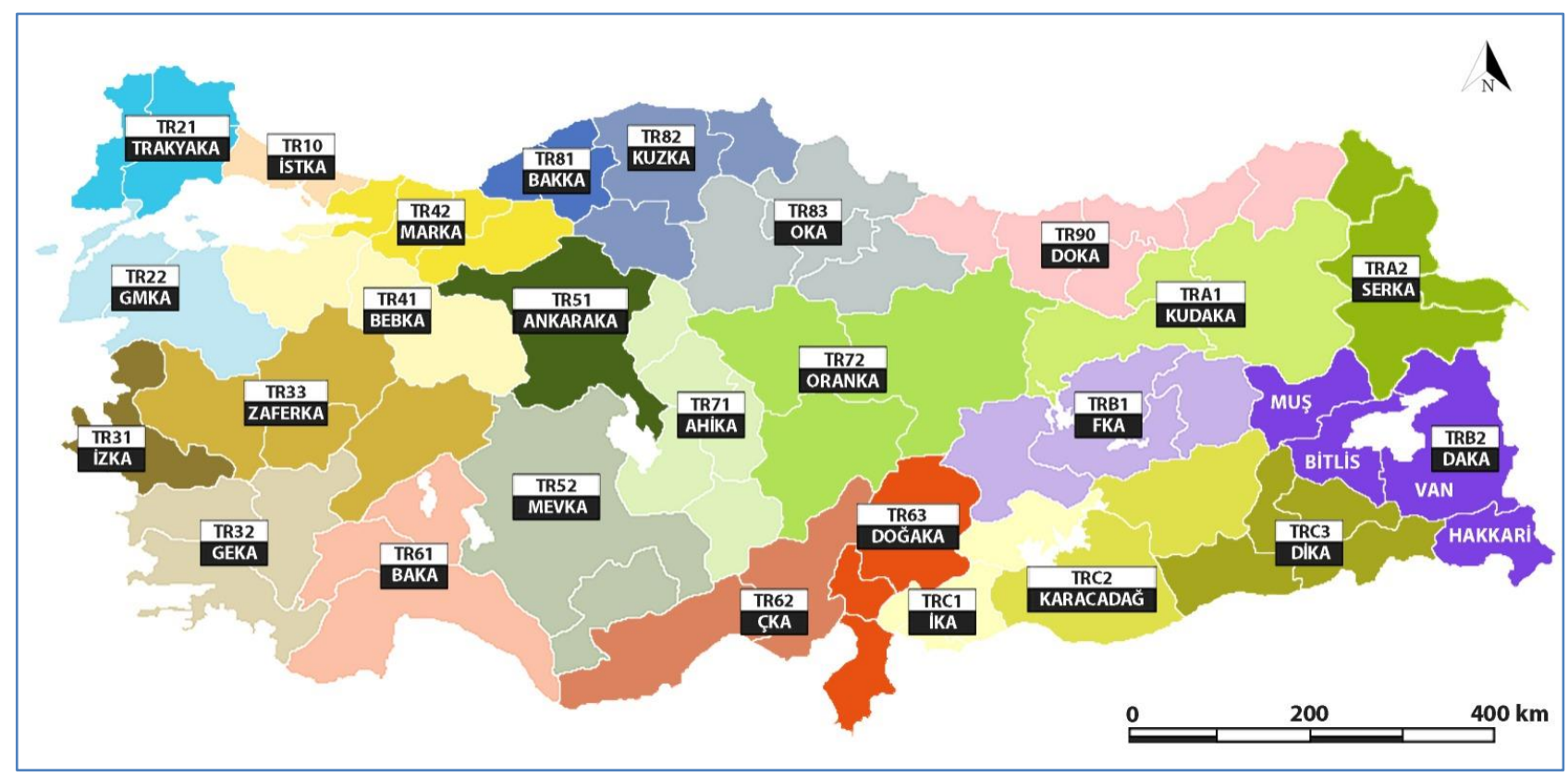

Figure 1: EADA City Boundaries (Index Development Agency of Turkey, 2017)

EADA has prepared the TRB2 Region 2011-2013 Regional Plan covering Bitlis, Muş, Hakkari and Van cities, the TRB2 Region Regional Plan for 2014-2023 Period and the Vision 2023 Common Intellect Strategic Action Plan for Van City and Districts. 
The Regional Plan for TRB 2 Region 2014-2023 period aimed to identify and support areas where the Region is comparatively superior and below the country average by the Eastern Anatolia Development Agency. Accordingly, three development perspectives, 18 main targets and 65 strategies for the implementation of these targets have been determined. The first development perspective is sectoral growth within the scope of economic transformation and growth (agriculture, industry, mining, tourism, energy), the second development perspective is improving the quality of urban life as livable spaces (air-water-sewage-waste management etc.); like education, health, cultural, social, religious and sports facilities, public education centers, technical infrastructure and recreation areas, accessibility in transportation and finally the third development perspective is aimed at developing social and human capital as a strong society (EADA, 2014). In terms of cultural policies, there are no direct culture-oriented targets and strategies in the Regional Plan. However, when we look at the content of the projects, it is seen that many projects have been developed for culture. When the TRB2 Region 2014-2023 Regional Plan is evaluated in terms of cultural policies, the protection of natural and cultural heritage and the development of human capital draw attention first of all with the objective of vision. In the first development perspective, which is "Economic Transformation and Growth", the branding strategy is adopted and the determination of geographical signs and registration of local products (ushkun, Gevaş beans, Sıhke melon, Norduz sheep and goat, Van breakfast, Bahçesaray walnut, Çatak honey, Edremit apple, Van mullet, etc.) show that gastronomy within the cultural heritage framework is given importance within the scope of traditional products. In addition, natural and historical values are evaluated in terms of tourism within the scope of Urartu route.

The images of the cities in the region were determined on a sectoral basis by giving importance to the urban identity within the scope of livable spaces. Accordingly, the cities were evaluated as follows: Hakkari; Mining and Logistics City, Muş; Agricultural Production and Agricultural Industry City, Bitlis; Tourism Focus and Museum City, Van; Regional Center City Based on Commercial Services and Industrial Sectors. Considering the historical and cultural potential of the city of Van, instead of a city of culture and tourism, it is considered a regional center for commercial, services and industrial sectors. This is due to the fact that Van is seen as a geopolitical location and attraction center in the region.

In the second perspective, the development of urban design works for urban identity and urban fabric can be evaluated in terms of renewing/creating the urban image. Particularly within the scope of "Urban Identity Oriented Urban Economy and Macro Form Research Project" and "Urban Identity Oriented Architectural Texture Research and Urban Design Project", the establishment of the identity of the city, creation of attraction center areas, determination of the spatial experiences and the periodic architectural patterns determined by oral history, exhibiting works of art and artistic activities in public and private spheres with its architectural texture and history, include direct cultural policies and they are considered important to read the relationship between urban design and culture.

In the third perspective, Strong Society, the use of educational programs to improve/strengthen these structures (EU Lifelong Learning Programs) with emphasis on social and human capital, and cultural centers to enrich the social life style to bring together multiple identities and cultures in the region and the establishment of youth and sports centers were presented as project proposals.

Finally, in the Vision 2023 Joint Reasoning Strategic Action Plan of Van City and its districts, the 2023 Vision of Van City was determined to be the Capital of the East, the Center of the Middle East and the Near East with its Competitive Economy, High Quality of Life, Advanced Human Capital (EADA, 2015). In line with this vision, strategic objectives and projects aimed at economic, human and institutional capacity in the region have been established. The plan does not include a direct culture heading for the vision and aims, and the cultural policies are read from action plans and projects. The importance of cultural heritage values (gastronomy, historical and cultural areas, handicrafts, and endemic species) has been attached importance for the revival and promotion of the tourism sector in actions aimed at regional and individual welfare levels. Although the plan of actions that proposes the preservation of Van architecture, the introduction of local tastes, the establishment of the Ethnographic Museum and the archaeological excavations are evaluated within the framework of tourism, they are directly related to cultural policies.

\section{MATERIAL AND METHOD}

The research focuses on whether there is a relationship between the cultural economy and development policies in the investments of the international actor EU and the regional actor Eastern Anatolia Development Agency (EADA) in the TRB2 Region, where regional inequality is the highest in Turkey. The research aims to assess the development problem of the Region through the cultural economy in accord with the investments of the actors. Research problem has been determined as "Could investments in the cultural economy be the impetus for regional development, given there are grave regional inequalities and development problems in TRB2 Region?" Research questions for the research problem are given below: 
- What are the development issues of TRB2 region?

- Which sectors are shaped by the economic structure of TRB2 Region?

- Which actors direct regional development policies in TRB2 region?

- Which Regional Development Programs did TRB2 Region benefit from within the scope of the EU Pre-Accession Assistance Program?

- How do EADA and the EU view the development issues of TRB2 region?

- How is culture defined in the strategy plans for EADA's development policies? What are the policies regarding culture?

- Which sectors did EADAP support within the scope of Regional Development Programs? Which of these grants fall into cultural economy and human development index?

- Which sectors did EADA support as a pivotal actor in Regional Development? Which of these grants were included in the cultural economy and human development index?

- Which activities were evaluated as cultural economy in the investments / grants / supports of the EU's 20042009 MEDA program EADAP and EADA in the TRB2 Region between 2009 and 2015?

- Which / which of the projects supported by the EU and EADA are directly or indirectly related to culture and culture economy?

Content analysis is used in the research. The content analysis aims to reach the concepts, categories, and themes that explain these data by examining them in more detail. In the content analysis, by focusing on the collected data, codes are constituted in events and facts repeated in the data set or that the participant emphasizes. Data analysis is performed from codes to categories and from categories to themes. In sum, data (codes) determined to be similar and related to each other are brought together within the framework of certain concepts (categories) and themes and interpreted (Bengtsson, 2016; Crabtree and Miller, 1999; Merriam and Grenier, 2019; Baltacl, 2019:377).

The data is examined and broken down into meaningful sections; ultimately, what each section means conceptually is revealed in the coding stage. These sections, which form a meaningful category on their own, are coded by the researcher (Neuman, 2012; Karataş, 2015: 74). Strauss and Corbin (1990) expressed that there are three types of coding. These are as follows: coding made according to pre-determined concepts, coding made according to the notions extracted from the data, and coding made in a general framework (Karataş, 2015; 75).

National development plans and TRB2 Regional Plans, in rapport with the scope of the research, were examined and policies for the cultural economy were determined by the content analysis method. Later, between 2004-2009, EADAP supported by the EU MEDA fund, and the investments made by EADA in the TRB2 Region between 2009-2015 were classified and evaluated according to the content of the investments within the scope of the institutional classification of actors, cultural economy and human development index (see table 2 and table 3 ).

\section{Classification of Investments in TRB2 Cities by Sectoral, Cultural Economy and Human Development Index}

It is aimed to determine the sectoral, human and cultural dimensions of the investments provided to TRB2 cities. For this purpose, investments were evaluated in the cultural economy classification developed by ISIC REV.4 / NACE REV.2, UNDP's Human Development Index (HDI) and UNCAD (2008), INTELI (2011), Aksoy and Enlil (2011). Accordingly, ISIC REV.4 / NACE REV.2 classification is used for the sectoral classification of investments in Van. This classification, which determines the main activities of the sectors operating in the economic field and provides international data comparison, aims primarily to determine the sectoral distribution of investments in Van.

The Human Development Index (HDI) was developed with reference to the work of UNDP (2015), Mushkin (1962), Schultz (1968), Lucas (1988) and Sab and Smith (2001). Accordingly, health investments as life expectancy index and educational investments as education index were evaluated. In the income index included in the human development index, since the GDP per capita indicator is used and there is no such content in investments, this index is not taken into consideration within the scope of the research. In line with these evaluations, the Human Development Index is classified as education, health and education and health on the basis of investments as in Table 2. According to this classification, educational activities include school building, vocational and cultural trainings, capacity building trainings, human rights trainings, and vocational training courses. Health activities include sports activities, the construction of sports complexes, scientific studies for the health sector and infrastructure works for human health. 


\begin{tabular}{|c|c|c|}
\hline \multicolumn{3}{|c|}{ Table 2:Classification of Human Development Index } \\
\hline \multicolumn{3}{|c|}{ HUMAN DEVELOPMENT INDEX * } \\
\hline EDUCATION & HEALTH & EDUCATION AND HEALTH \\
\hline $\begin{array}{l}\text { School construction, vocational and cultural } \\
\text { trainings, community centers, construction of } \\
\text { educational centers and cultural centers, } \\
\text { infrastructure and superstructure works in } \\
\text { schools, strategy reports, feasibility studies, } \\
\text { workshops and seminars, training activities for } \\
\text { capacity building of institutions and NGOs, } \\
\text { vocational personal development trainings, } \\
\text { vocational training courses, human rights } \\
\text { education, EU Education Programs (Lifelong } \\
\text { Learning and Youth Programs), educational } \\
\text { activities for autistic children, educational } \\
\text { activities on democracy and human rights. }\end{array}$ & $\begin{array}{l}\text { Sports activities (basketball, volleyball, } \\
\text { swimming, etc.), construction of sports } \\
\text { facilities (sports complexes and sports fields), } \\
\text { R \& D studies for the health sector, dialysis } \\
\text { center, production of diagnostic laboratory } \\
\text { kit, medical plant research, drinking water } \\
\text { for human health rehabilitation and } \\
\text { treatment systems and sewer construction, } \\
\text { patient care, outdoor nature sports, } \\
\text { molecular level diagnostic method. }\end{array}$ & $\begin{array}{l}\text { Training activities for the health sector (sports } \\
\text { trainings, human health trainings, physician } \\
\text { training abroad). }\end{array}$ \\
\hline
\end{tabular}

Finally, the classification for cultural economy was developed by UNCTAD (2008), INTELI (2011), Aksoy and Enlil (2011). In this classification, subclasses are defined under the headings "cultural heritage", "art", "cultural industries" and "creative services". Investments are evaluated in 4 main classes and subclasses of these classes (see table 3 ).

\begin{tabular}{|c|c|}
\hline \multicolumn{2}{|r|}{ Table 3:Cultural Economy Classification* } \\
\hline Classification & Subclasses \\
\hline $\begin{array}{l}\text { 1.Cultural } \\
\text { heritage }(\mathrm{CH})\end{array}$ & $\begin{array}{l}\text { It is a collection of tangible and intangible works created by people in the historical process. Tangible heritage includes the } \\
\text { historical, natural and cultural structures; intangible cultural heritage covers language, rituals, traditions and cultural expressions. } \\
\text { 1.1. Handicrafts: Jewelry, weaving-textile, ceramics and wood crafts, art restoration and so on. } \\
\text { 1.2. Traditional Gastronomy: It includes eating and drinking culture shaped by traditional methods and cultural structure of } \\
\text { society. } \\
\text { 1.3. Historical, cultural and natural heritage (Tangible Heritage): Museums, archives, libraries, archaeological sites (protected } \\
\text { areas), monuments, natural parks, nature conservation areas and so on. } \\
\text { 1.4. Traditional Building Materials/Traditional Products: Natural building materials used in Traditional Architecture/Folk } \\
\text { Architecture (such as ahlat stone, travertine, wood, etc.). } \\
\text { 1.5. Intangible Cultural Heritage: Oral traditions and expressions together with the language that acts as a carrier in transferring } \\
\text { intangible cultural heritage. Performing arts (traditional music, dances, theaters, etc.), social practices, rituals, festivals, practices } \\
\text { and knowledge of the universe and nature }\end{array}$ \\
\hline 2. $\operatorname{Art}(A)$ & $\begin{array}{l}\text { 2.1. Visual arts: Painting, sculpture contemporary arts, photography. } \\
\text { 2.2. Performing Arts: Live music, theater, dance, opera, circus, etc. }\end{array}$ \\
\hline $\begin{array}{l}\text { 3. Culture } \\
\text { Industries }(\mathrm{Cl})\end{array}$ & $\begin{array}{l}\text { It is composed of television, radio, internet broadcasting, press and broadcasting and film industries which can be called as media } \\
\text { in broad sense. } \\
\text { 3.1. Publishing and print media } \\
\begin{array}{l}\text { 3.2. Radio and Television } \\
\text { 3.3. Music Industry } \\
\text { 3.4. Film Industry }\end{array}\end{array}$ \\
\hline $\begin{array}{l}\text { 4. Creative } \\
\text { Services (CS) }\end{array}$ & $\begin{array}{l}\text { It includes services that require creativity together with cultural and entertainment services. } \\
\text { 4.1. Design: Fashion, interior architecture, graphics, jewelry, etc. } \\
\text { 4.2. New Media and Software: Software, video games, content production and management } \\
\text { 4.3. Architecture: Architectural services } \\
\text { 4.4. Advertising: Advertising Services } \\
\text { 4.5. Culture and Entertainment Services: Cultural Centers, festival organizations, cultural activities (trips, festivals, etc.) }\end{array}$ \\
\hline
\end{tabular}

\section{EADA Support/Grant Programs}

EADA supports the following projects or activities of local administrations, universities, other public institutions and organizations, professional public institutions, non-governmental organizations, profit-making enterprises, cooperatives, associations and other real and legal persons (EADA, 2014a). EADA Financial Support Program provides Direct Finance Support, Direct Activity Support, Guided Project Support, Interest Support and Non-Interest Credit Support and Technical Support Program. The types of support are: Financial Support Program (MDP) ${ }^{1}$, Direct Activity

\footnotetext{
${ }^{1}$ Between 2009 and 2015, 12 programs were implemented within the scope of Financial Support Programs. These are: Model Cattle Farming Expansion Financial Support Program, Small Scale Infrastructure Financial Support Program for the Strengthening of Investment Infrastructure, Encouraging the Use of Renewable Energy Resources Financial Support Program, Fruit and Vegetable Improvement Program in Hakkari City, Financia Support Program for Small Scale Infrastructure Projects for Strengthening Investment and Tourism Infrastructure (2013, 2015), Economic Development Financial Support Program, Strong Entrepreneurship Financial Support Program, Small Scale Infrastructure Projects Financial Support
} 
Support Program (DFDP), Technical Support Program (TDP) and Attraction Center Support Program (CMDP). Between 2009 and 2015, 516 projects $(88,666,601$ \$) were supported under the titles of Financial Support, Direct Activity Support, Technical Support and Support Centers of Attraction Centers within the scope of EADA Support Program of TRB2 cities (Van, Bitlis, Muş, Hakkari) (see table 4). According to this, 205 of the 516 projects to Van, to Muş, 108 of them to Hakkari and 94 of them to Bitlis were transferred. When these projects are evaluated in terms of their ratio to the total budget and number of projects, $51.34 \%$ of the total budget has been transferred to the Financial Support Program, $1.77 \%$ has been transferred to the Direct Activity Support Program, $0.94 \%$ has been transferred to the Technical Support Program and $45.95 \%$ to the Attraction Center Support Program. Van has 111 projects under the Financial Support Program, 24 projects under the Direct-Action Support Program, 65 projects under the Technical Support Program and finally under the Support Centers Program grant support received through 5 projects. Accordingly, $67.20 \%$ of the total $88,666,601 \$$ grant support for 516 projects was transferred to Van. According to this, Van has benefited the most from the grant support. When we look at the distribution of 516 projects belonging to EADA at the regional level according to cultural economy and human development index between 2009-2015, 82 of them are in cultural economy class $(31,830,320 \$)$ and 195 of them are in human development index class $(4,602,268 \$)$ (see figure 2).

\begin{tabular}{|c|c|c|c|c|c|c|c|}
\hline Date & City & $\begin{array}{l}\text { EADA Corporate } \\
\text { Classification } \\
\text { (Number of } \\
\text { Projects) } \\
\end{array}$ & $\begin{array}{l}\text { Grant Support } \\
\text { (USD)* }\end{array}$ & $\begin{array}{l}\text { Cultural } \\
\text { Economy } \\
\text { (Number of } \\
\text { Projects) } \\
\end{array}$ & $\begin{array}{l}\text { Grant Support } \\
\text { (USD)* }\end{array}$ & $\begin{array}{l}\text { Human } \\
\text { Development Index } \\
\text { (Number of } \\
\text { Projects) }\end{array}$ & $\begin{array}{l}\text { Grant Support } \\
\text { (USD)* }\end{array}$ \\
\hline \multirow{25}{*}{$\begin{array}{l}2009- \\
2015\end{array}$} & \multirow{5}{*}{ BitLis } & MDP:53 & $9,024,405$ & MDP:12 & $3,218,912$ & MDP:2 & 225,664 \\
\hline & & DFDP:10 & 311,620 & DFDP:9 & 301,574 & DFDP:1 & 31,981 \\
\hline & & TDP:31 & 138,728 & TDP:1 & 4,453 & TDP:31 & 138,728 \\
\hline & & CMDP:0 & 0 & CMDP:0 & 0 & CMDP:0 & 0 \\
\hline & & TOTAL:94 & $9,474,753$ & TOTAL:22 & $3,524,938$ & TOTAL:34 & 396,373 \\
\hline & \multirow{5}{*}{ HAKKARI } & MDP:57 & $8,081,571$ & MDP:9 & $3,116,461$ & MDP:1 & 29,579 \\
\hline & & DFDP:10 & 281,581 & DFDP:5 & 155,057 & DFDP:2 & 52,005 \\
\hline & & TDP:41 & 208,702 & TDP:0 & 0 & TDP:41 & 208,702 \\
\hline & & CMDP:0 & 0 & CMDP:0 & 0 & CMDP:0 & 0 \\
\hline & & TOTAL:108 & $8,571,854$ & TOTAL:14 & $3,271,518$ & TOTAL:44 & 290,286 \\
\hline & \multirow{5}{*}{ MUŞ } & MDP:62 & $10,585,300$ & MDP:5 & 517,121 & MDP:1 & 428,221 \\
\hline & & DFDP:10 & 272,604 & DFDP:4 & 144,212 & DFDP:0 & 0 \\
\hline & & TDP:37 & 178,790 & TDP:2 & 7,180 & TDP:37 & 178,790 \\
\hline & & CMDP:0 & 0 & CMDP:0 & 0 & CMDP:0 & 0 \\
\hline & & TOTAL:109 & $11,036,694$ & TOTAL:11 & 668,513 & TOTAL:38 & 607,012 \\
\hline & \multirow{5}{*}{ VAN } & MDP:111 & $17,831,853$ & MDP:17 & $3,124,279$ & MDP:7 & $2,782,529$ \\
\hline & & DFDP:24 & 707,705 & DFDP:8 & 260,614 & DFDP:8 & 231,472 \\
\hline & & TDP:65 & 301,672 & TDP:8 & 48,438 & TDP:64 & 294,597 \\
\hline & & CMDP:5 & $40,742,069$ & CMDP:2 & $20,932,019$ & CMDP:0 & 0 \\
\hline & & TOTAL:205 & $59,583,299$ & TOTAL:35 & $24,365,350$ & TOTAL:79 & $3,308,598$ \\
\hline & \multirow{5}{*}{$\begin{array}{l}\text { TRB2 } \\
\text { (BiTLis, } \\
\text { HAKKARi, } \\
\text { MUŞ, VAN) }\end{array}$} & MDP:283 & $45,521,713$ & MDP:43 & $9,976,773$ & MDP:11 & $3,465,994$ \\
\hline & & DFDP:54 & $1,573,511$ & DFDP:26 & 861,457 & DFDP:11 & 315,457 \\
\hline & & TDP:174 & 827,892 & TDP:11 & 60,071 & TDP:173 & 820,817 \\
\hline & & CMDP:5 & $40,742,069$ & CMDP:2 & $20,932,019$ & CMDP:0 & 0 \\
\hline & & TOTAL:516 & $88,666,601$ & TOTAL:82 & $31,830,320$ & TOTAL:195 & $4,602,268$ \\
\hline
\end{tabular}

Within the scope of EADA programs, 213 projects were carried out by public institutions, 210 projects by companies (SMEs), 64 projects by non-governmental organizations and 30 projects by real persons. 82 cultural projects at regional level constitute $35.90 \%$ of the total grant support. When we look at the distribution of these projects by cities, the grant supports are as follows: Van 35 projects, Bitlis 22 projects, 14 projects in Hakkari and Muş 11 projects. According to this, $76.55 \%$ of the support evaluated within the scope of culture-based investments was provided to Van and Van became the city that received the most investment. Within the scope of EADA support programs, the highest cultural investment was realized in MDP with 43 projects. Within the scope of cultural economy, 44 projects were carried out

Program for Strengthening Faith Tourism Infrastructure in Hakkari (HSFTIP) is the Financial Support Program for Promoting Competitiveness and the Financial Support Program for Supporting Small Entrepreneurship (EADA, 2014a). 
by public institutions, 15 projects by companies (SMEs), 12 projects by natural persons and 11 projects by nongovernmental organizations.

Within the scope of the human development index, 195 out of 516 projects at the regional level (TRB2) were evaluated as education and health investments and a total of 4,602,268 \$ (5.19\%) was granted. Training investments consist of training activities aimed at capacity building of institutions, vocational training, construction of training center and personal development trainings. Health investments consist of Research and Development (R\&D) studies, dialysis center, diagnostic laboratory kit production and projects for medical plant research. The projects that are not included in the classification mainly include agriculture, industrial capacity development projects, tourism infrastructure projects, park projects and feasibility studies. Under the human development index, 142 projects were carried out by public institutions, 42 projects by non-governmental organizations, 10 projects by companies (SMEs) and 1 project by real persons.

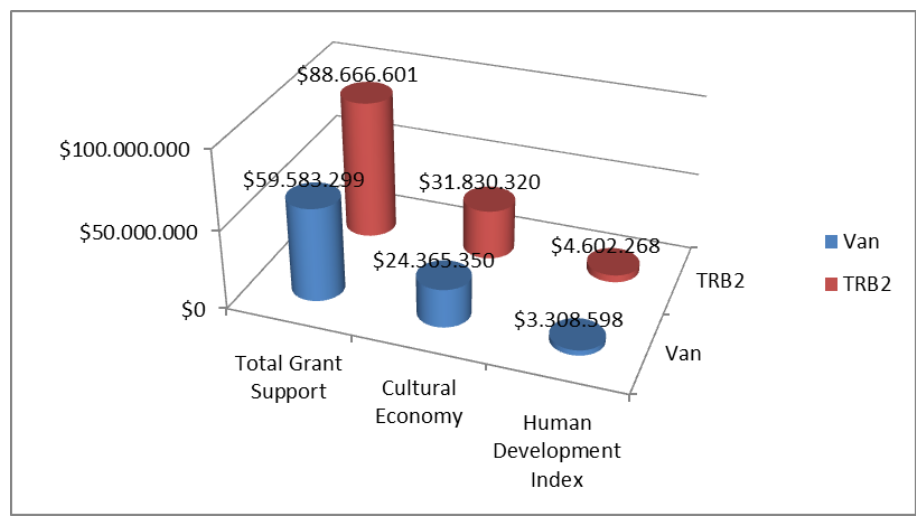

Figure 2: Distribution of EADA Projects by Cultural Economy and Human Development Index Between 2009 and 2015

Table 5 shows that all projects supported under EADA and classified according to ISIC REV.4 / NACE REV.2. According to this classification, the highest number of projects in TRB2 region was supported for education (173), manufacturing (132), construction (80), agriculture, forestry and fishing (45) and professional, scientific and technical activities (42). According to the cultural economy, this amount constitutes $35.90 \%$ of the total grant support. According to sector classification, more cultural investments took place in construction (22), professional scientific and technical activities (18) and education (11) sectors. When the projects are analyzed, it is seen that the production, mining, construction and food sectors are prioritized for SMEs. Agriculture and animal husbandry projects include the establishment of large livestock enterprises, animal market and slaughterhouse applications, greenhouse production, capacity building in milk and milk products and infrastructure works for animal productivity. The tourism sector mainly includes restoration projects and projects to support tourism by using natural resources. In the training activities, activities aimed at increasing the institutional capacity are done.

\begin{tabular}{|c|c|c|c|c|c|}
\hline \multicolumn{4}{|c|}{ TRB2 REGION (VAN, BiTLIS, MUŞ, HAKKARi) } & \multicolumn{2}{|c|}{ VAN } \\
\hline CODE & DESCRIPTION & $\begin{array}{c}\text { GENERAL } \\
\text { PROJECT COUNT }\end{array}$ & $\begin{array}{l}\text { CULTURAL ECONOMY } \\
\text { PROJECT COUNT }\end{array}$ & $\begin{array}{c}\text { GENERAL } \\
\text { PROJECT COUNT }\end{array}$ & $\begin{array}{l}\text { CULTURAL ECONOMY } \\
\text { PROJECT COUNT }\end{array}$ \\
\hline A & Agriculture, Forestry and Fisheries & 45 & 6 & 12 & 2 \\
\hline B & Mining and Quarrying & 7 & 6 & 2 & 2 \\
\hline $\mathrm{C}$ & Production & 132 & 8 & 59 & 2 \\
\hline E & $\begin{array}{l}\text { Water Supply: Sewage, Waste } \\
\text { Management and Improvement Activities }\end{array}$ & 1 & 0 & 1 & 0 \\
\hline $\mathbf{F}$ & Construction & 80 & 22 & 31 & 11 \\
\hline G & $\begin{array}{l}\text { Wholesale and Retail Trade: Repairs Of } \\
\text { Motor Vehicles and Motorcycles }\end{array}$ & 1 & 1 & 1 & 1 \\
\hline $\mathbf{H}$ & Transportation and Storage & 1 & 0 & 1 & 0 \\
\hline I & $\begin{array}{l}\text { Accommodation and Food Service } \\
\text { Activities }\end{array}$ & 12 & 3 & 2 & 1 \\
\hline J & Information and Communication & 7 & 4 & 5 & 3 \\
\hline M & $\begin{array}{l}\text { Professional, Scientific and Technical } \\
\text { Activities }\end{array}$ & 42 & 18 & 19 & 6 \\
\hline $\mathbf{N}$ & $\begin{array}{l}\text { Administrative and Support Service } \\
\text { Activities }\end{array}$ & 6 & 3 & 0 & 0 \\
\hline $\mathbf{P}$ & Education & 173 & 11 & 65 & 7 \\
\hline $\mathbf{Q}$ & Human Health and Social Work Activities & 7 & 0 & 7 & 0 \\
\hline $\mathbf{S}$ & Other Service Activities & 2 & 0 & 0 & 0 \\
\hline \multicolumn{2}{|l|}{ TOTAL } & 516 & 82 & 205 & 35 \\
\hline
\end{tabular}


Table 6: Evaluation of The Projects Within The Scope of EADA Support Program in Terms of Cultural Economy Between 2009-2015

\begin{tabular}{|c|c|c|c|c|}
\hline \multicolumn{5}{|c|}{ TRB2 REGION (BITLIS, HAKKARI, MUŞ, VAN) } \\
\hline DATE & \multicolumn{2}{|l|}{ CULTURAL ECONOMY } & $\begin{array}{l}\text { NUMBER of } \\
\text { PROJECTS }\end{array}$ & PROJECT CONTENT \\
\hline \multirow{11}{*}{$\begin{array}{l}2009- \\
2015\end{array}$} & CULTURAL HERITAGE (CH) & $\begin{array}{l}\text { Traditional Gastronomy } \\
\text { Historical, cultural and natural heritage } \\
\text { (tangible heritage) } \\
\text { Traditional products/traditional building } \\
\text { material } \\
\text { Handicrafts } \\
\text { Intangible heritage }\end{array}$ & $\begin{array}{l}20 \\
28 \\
7 \\
8 \\
2\end{array}$ & $\begin{array}{l}\text { Local products (honey, cheese (herbal } \\
\text { cheese, Muş kashar), sheep yogurt, natural } \\
\text { water sources, local dishes) } \\
\text { Nature protection areas, Mus tulips, } \\
\text { historical sites, museums } \\
\text { Natural Heritage Marble } \\
\text { Bindallı, needlework, ceramic making } \\
\text { Kyrgyz culture, Kurdish language }\end{array}$ \\
\hline & \multicolumn{2}{|l|}{ TOTAL } & \multicolumn{2}{|l|}{63} \\
\hline & CREATIVE SERVICES (CS) & $\begin{array}{l}\text { Design and Architecture } \\
\text { Design }\end{array}$ & $\begin{array}{l}3 \\
2\end{array}$ & $\begin{array}{l}\text { Architectural design } \\
\text { Patented tillage harrow, design guide }\end{array}$ \\
\hline & \multicolumn{2}{|l|}{ TOTAL } & \multicolumn{2}{|l|}{5} \\
\hline & $\begin{array}{l}\text { CULTURAL INDUSTRIES } \\
\text { (CI) }\end{array}$ & $\begin{array}{l}\text { Film industry } \\
\text { Publishing and print media }\end{array}$ & $\begin{array}{l}3 \\
4 \\
\end{array}$ & $\begin{array}{l}\text { Film and cinema hall for the visually impaired } \\
\text { Books, guides, newspapers }\end{array}$ \\
\hline & \multicolumn{2}{|l|}{ TOTAL } & \multicolumn{2}{|l|}{7} \\
\hline & ART (A) & Performing arts & 5 & Drama, exhibition and show center \\
\hline & \multicolumn{2}{|l|}{ TOTAL } & \multicolumn{2}{|l|}{5} \\
\hline & $\begin{array}{l}\text { CREATIVE SERVICES AND } \\
\text { CULTURAL HERITAGE (CS } \\
\text { and CH) }\end{array}$ & $\begin{array}{l}\text { Historical, cultural and natural heritage } \\
\text { (tangible heritage) and architecture and } \\
\text { design }\end{array}$ & 2 & $\begin{array}{l}\text { Hosap Castle harem site restoration project } \\
\text { drawing, sample Bitlis house survey, } \\
\text { restoration and restitution project }\end{array}$ \\
\hline & \multicolumn{2}{|l|}{ TOTAL } & \multicolumn{2}{|l|}{2} \\
\hline & \multicolumn{2}{|l|}{ GRAND TOTAL } & 82 & \\
\hline
\end{tabular}

Between 2009 and 2015, EADA formed support programs aimed to accelerate economic and social development by focusing on rural and local development at regional scale (TRB2), to create business and investment opportunities, to support research and development projects, to increase regional competition day and to improve institutional capacities of public institutions and non-governmental organizations. These support programs consist of Financial Support Program, Direct Activity Support Program, Technical Support Program and Attraction Center Support Program. There is no direct support program for culture in these program titles and subheadings.

Although EADA's other programs do not seek direct cultural investments in the content of the projects, there are cultural elements in the supported projects. While MDP aims at developing the tourism infrastructure and superstructure, especially in the tourism title, supporting natural, cultural and historical heritage values, which are an important resource in the diversity of tourism, is considered important in terms of cultural policies. Although investments in cultural heritage have been made under the title of tourism, it can be said that EADA uses/evaluates culture as a tool for tourism.

\section{Pre-Accession Financial Assistance Period (2000-2006) MEDA Program}

The European Union gives priority to policies aiming to reduce inequality between regions. Since 2003, the EU PreAccession Financial Assistance Program began implementing the Regional Development Program in Turkey. Eastern Anatolia Development Program (EADAP), covering the TRB2 region, was supported by a grant from the EU MEDA fund (Savrul, 2012). Accordingly, it is seen that the TRB2 Region and the city of Van, which is the research area, are primarily included in the support mechanisms (grants) for the EU's regional policies. Eastern Anatolia Development Program (EADAP) was chosen as the research subject by the EU since it was the first and integrated development program for the TRB2 region before the Establishment of the Development Agencies.

MEDA (Mediterranean Economic Development Area) Program was included in the EU Pre-Accession Financial Assistance Program 2000-2006. The program is the main financial assistance mechanism of the implementation of the European Mediterranean Cooperation. MEDA is the only financial instrument of cooperation activities and includes support in three areas: economic transition, economic and social development, regional and border cooperation. 11 Programs are addressed in two separate categories, as national and regional.

The MEDA Program / Eastern Anatolia Development Program (EADAP) aimed to promote and support technical cooperation activities aimed at developing education and skills for employment and income generation, capacity building and ensuring the access of rural populations, especially women and girls, to basic social services. In this way, it aims to develop sustainable and participatory development models in which general, social and economic development is realized. EADAP, which was established in 2000 and implemented in TRB2 region (Van, Muş, Bitlis and Hakkâri) between 2004 and 2009 for this purpose. The program is focused on four components. These are: Agriculture and Rural 
Development (TKK), Small and Medium Enterprises (KOBi), Tourism and Environment (TÇ) and Social Development (SK) (EADAP, 2007).

Between 2004 and 2009, 325 projects $(35,122,069 \$)$ were supported under the title of Agriculture and Rural Development, SME, Tourism and Environment and Social Development Grant Programs under the Pre-Accession Financial Assistance MEDA Program of TRB2 cities (Van, Bitlis, Muş and Hakkari).

The projects and grants are transferred as following: 171 of the 325 projects for Van, 66 of them for Bitlis, 50 of them for Muş and 38 of them for Hakkari (see table 7). When these projects are evaluated in terms of their ratio to the total budget and number of projects, $43.73 \%$ of the total budget belongs to the Agriculture and Rural Development Program with 157 projects, $15.77 \%$ to the SME Program with 72 projects, $30.58 \%$ to the Tourism and Environment Program with 49 projects and $9.92 \%$ were transferred to the Social Development Program with 47 projects. Accordingly, the highest support was provided to the Agriculture and Rural Development Program and the Tourism and Environment Program in the TRB2 region. According to this, Van City received the highest support at TRB2 region level. The amount of support provided to Van constitutes $53.82 \%$ of the total budget. When we look at the distribution of 325 projects of MEDA according to cultural economy and human development index at regional level between 2004-2009, 58 of them are in cultural economy class $(6,764,709 \$)$ and 122 of them are in human development index class $(14,613,197 \$$ ) (see figure 3).

Under the MEDA program, 95 projects were carried out by public institutions, 72 projects by companies (SMEs), 88 projects by non-governmental organizations and 70 projects by farmer groups. At the regional level, 58 cultural projects constitute $19.26 \%$ of the total grant support. When we look at the distribution of these projects by cities: Van realized 32 projects, Bitlis 12 projects, Hakkari 11 projects and Muş 3 projects.

According to this, $56.42 \%$ of the support evaluated within the scope of culture-based investments was provided to Van and Van became the city that received the most investment. Within the scope of MEDA programs, the highest amount of cultural investment was realized in Agriculture Rural Development Grant Program with 25 projects. In addition, 16 projects were supported in the scope of Tourism and Environment Grant Program, 12 projects in SME Grant Program and 5 projects in Social Development Grant Program. According to the ISIC REV.4 / NACE REV.2 classification, the highest number of projects were supported by agriculture, forestry and fisheries (111), education (81), manufacturing (57) and construction (48) (see table 8).

\begin{tabular}{|c|c|c|c|c|c|c|c|}
\hline Date & City & $\begin{array}{l}\text { MEDA Corporate } \\
\text { Classification (Number } \\
\text { of Projects) }\end{array}$ & $\begin{array}{l}\text { Grant Support } \\
\text { (USD)* }\end{array}$ & $\begin{array}{l}\text { Cultural } \\
\text { Economy } \\
\text { (Number of } \\
\text { Projects) }\end{array}$ & $\begin{array}{l}\text { Grant } \\
\text { Support } \\
\text { (USD)* }\end{array}$ & $\begin{array}{l}\text { Human Development } \\
\text { Index (Number of } \\
\text { Projects) }\end{array}$ & $\begin{array}{l}\text { Grant Support } \\
\text { (USD)* }\end{array}$ \\
\hline \multirow{5}{*}{$\begin{array}{l}2004- \\
2009\end{array}$} & \multirow{5}{*}{ BiTLIS } & TKK: 31 & $2,746,544$ & TKK:4 & 382,370 & TKK:6 & 429,331 \\
\hline & & KOBi: 24 & $2,014,490$ & KOBi: 4 & 376,638 & Кові:0 & 0 \\
\hline & & TÇ:5 & $1,134,951$ & TÇ:3 & 649,692 & TÇ:3 & 623,070 \\
\hline & & SK:6 & 498,303 & SK:1 & 54,184 & SK:6 & 498,303 \\
\hline & & TOTAL:66 & $6,394,291$ & TOTAL:12 & $1,462,884$ & TOTAL:15 & $1,550,704$ \\
\hline \multirow{5}{*}{$\begin{array}{l}2004- \\
2009\end{array}$} & \multirow{5}{*}{ HAKKARI } & TKK:19 & $1,769,749$ & TKK:6 & 560,993 & TKK:3 & 296,779 \\
\hline & & KOBİ:8 & 625,336 & KOBI: 2 & 180,434 & KOBi:1 & 69,631 \\
\hline & & TÇ:4 & 704,647 & TÇ:3 & 473,740 & TÇ:4 & 704,647 \\
\hline & & SK:7 & 507,212 & SK:0 & 0 & SK:7 & 507,212 \\
\hline & & TOTAL:38 & $3,606,944$ & TOTAL:11 & $1,215,167$ & TOTAL:15 & $1,578,269$ \\
\hline \multirow{5}{*}{$\begin{array}{l}2004- \\
2009\end{array}$} & \multirow{5}{*}{ MUŞ } & TKK:23 & $2,240,750$ & TKK:2 & 218,982 & TKK:6 & 406,018 \\
\hline & & KOBi:8 & 449,820 & KOBi:1 & 50,746 & KOBi:0 & 0 \\
\hline & & TÇ:11 & $3,068,967$ & TÇ:0 & 0 & TÇ:9 & $2,532,594$ \\
\hline & & SK:8 & 458,266 & SK:0 & 0 & SK:8 & 458,266 \\
\hline & & TOTAL:50 & $6,217,803$ & TOTAL:3 & 269,728 & TOTAL:23 & $3,396,878$ \\
\hline \multirow{5}{*}{$\begin{array}{l}2004- \\
2009\end{array}$} & \multirow{5}{*}{ VAN* } & TKK:84 & $8,600,491$ & TKK:13 & $1,175,033$ & TKK:31 & $3,827,440$ \\
\hline & & KOBi:32 & $2,449,117$ & KOBi:5 & 348,408 & KOBi:4 & 259,257 \\
\hline & & TÇ:29 & $5,830,284$ & TÇ:10 & $2,004,548$ & TÇ:11 & $2,205,135$ \\
\hline & & SK:26 & $2,023,139$ & SK:4 & 288,941 & SK:23 & $1,795,514$ \\
\hline & & TOTAL:171 & $18,903,031$ & TOTAL:32 & $3,816,930$ & TOTAL:69 & $8,087,345$ \\
\hline \multirow{5}{*}{$\begin{array}{l}2004- \\
2009\end{array}$} & \multirow{5}{*}{$\begin{array}{l}\text { TRB2 (BITLIS, } \\
\text { HAKKARI, MUŞ, } \\
\text { VAN) }\end{array}$} & TKK:157 & $15,357,537$ & TKK:25 & $2,337,378$ & TKK:46 & $4,959,568$ \\
\hline & & кOBi:72 & $5,538,763$ & кові:12 & 956,226 & кOBi:5 & 328,888 \\
\hline & & TÇ:49 & $10,736,985$ & TÇ:16 & $3,127,980$ & TÇ:27 & $6,065,446$ \\
\hline & & SK:47 & $3,486,920$ & SK:5 & 343,125 & SK:44 & $3,259,295$ \\
\hline & & TOTAL:325 & $35,122,069$ & TOTAL:58 & $6,764,709$ & TOTAL:122 & $14,613,197$ \\
\hline \multicolumn{8}{|c|}{$\begin{array}{l}\text { MEDA Program within the framework of the European Union Pre-Accession Financial Assistance Program and } 161 \text { projects in Van City alone, } 10 \text { projects in } \\
\text { Bitlis, Hakkari, Muş and Van cities were evaluated within the framework of Van due to the applications made by NGOs and institutions in Van city. Within the } \\
\text { scope of MEDA Program, } 18 \text { projects }(2,029,984 \$) \text { were included in both cultural economy and human development classes. In Van alone, } 11 \text { projects } \\
(1,193,768 \$) \text { were included in the cultural economy and human development class. } \\
\text { *Six-year average USD exchange rate sales calculated as } 1.61 \text { TL between } 2004 \text { and } 2009 .\end{array}$} \\
\hline
\end{tabular}




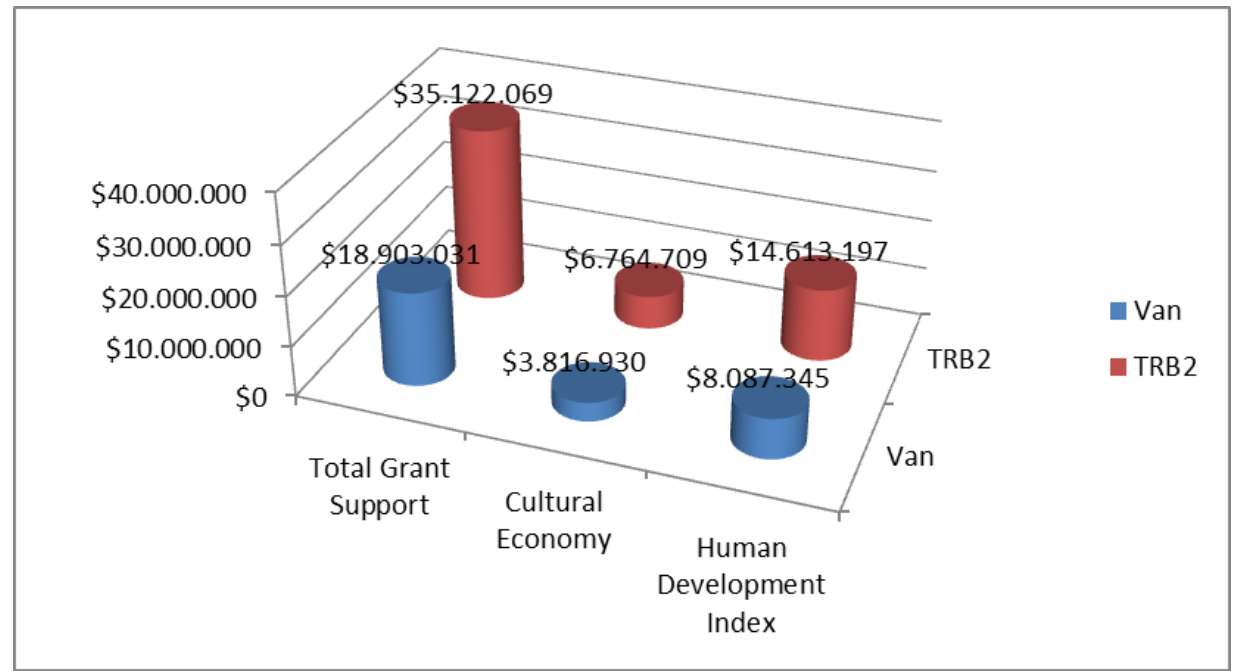

Figure 3: Distribution of MEDA Projects by Cultural Economy and Human Development Index Between 2004 and 2009

\begin{tabular}{|l|l|l|l|l|l|}
\hline \multicolumn{2}{|c|}{ Table 8: Sectoral Classification of The Projects Of The EU Pre-Accession Financial Assistance MEDA Program Between 2004-2009 by } \\
\hline \multicolumn{7}{|c|}{ ISIC REV.4/NACE REV.2 } \\
\hline CODE & DESCRIPTION & $\begin{array}{l}\text { GENERAL } \\
\text { PROJECT COUNT }\end{array}$ & $\begin{array}{l}\text { CULTURE } \\
\text { ECONOMT } \\
\text { PROJECT COUNT }\end{array}$ & $\begin{array}{l}\text { GENERAL PROJECT } \\
\text { COUNT }\end{array}$ & $\begin{array}{l}\text { CULTURAL ECONOMY } \\
\text { PROJECT COUNT }\end{array}$ \\
\hline A & Agriculture, Forestry and Fisheries & 111 & 23 & 58 & 12 \\
\hline B & Mining and Quarrying & 1 & 1 & 0 & 0 \\
\hline C & Production & 57 & 11 & 27 & 5 \\
\hline E & $\begin{array}{l}\text { Water Supply: Sewage, Waste } \\
\text { Management and Improvement } \\
\text { Activities }\end{array}$ & 14 & 0 & 5 & 0 \\
\hline F & Construction & 48 & 10 & 22 & 6 \\
\hline G & $\begin{array}{l}\text { Wholesale and Retail Trade: Repairs Of } \\
\text { Motor Vehicles and Motorcycles }\end{array}$ & 1 & 0 & 1 & 0 \\
\hline H & Transportation and Storage & 1 & 0 & 1 & 0 \\
\hline J & Information and Communication & 4 & 3 & 2 & 2 \\
\hline M & $\begin{array}{l}\text { Professional, Scientific and Technical } \\
\text { Activities }\end{array}$ & 1 & 1 & 1 & 1 \\
\hline N & $\begin{array}{l}\text { Administrative and Support Service } \\
\text { Activities }\end{array}$ & 2 & 0 & 2 & 0 \\
\hline P & Education & 81 & 8 & 49 & 5 \\
\hline Q & $\begin{array}{l}\text { Human Health and Social Work } \\
\text { Activities }\end{array}$ & 3 & 0 & 2 & 0 \\
\hline S & Other Service Activities & 1 & 1 & 1 & 1 \\
\hline TOTAL & & $\mathbf{3 2 5}$ & $\mathbf{1 7 1}$ & $\mathbf{3 2}$ \\
\hline
\end{tabular}

When the projects are examined, it is seen that SME projects are mainly focused on manufacturing industry, construction, food and capacity building activities, agriculture and rural development projects, agriculture and animal husbandry sector development, vegetable and fruit production, fattening, fodder, fish and bee production and education activities. , pasture breeding and production of milk and dairy products, tourism and environmental projects, park, nature conservation, afforestation, solid waste management and training to raise environmental awareness and sewage, drinking water, waste water removal, stream reclamation, agricultural irrigation and cemetery infrastructure projects such as building projects, restoration for the tourism sector, promotion of natural and cultural values, vocational training and promotion activities for cultural parks and tourism, training for disadvantaged groups in the title of social development, development of handicrafts projects for health and vocational courses.

Within the scope of the human development index, 122 of 325 projects at the regional level were evaluated as education and health investments and a total of $14,613,197 \$(41.61 \%)$ was provided for grant support. According to MEDA classification, 46 of 122 projects were included in TKK, 5 of them were KOBI, 27 of them were TÇ and 44 of them were included in SK projects. 102 of these projects include education, 15 of them include health and 5 of them include both education and health. These training investments are: Training activities for capacity building of institutions, vocational training for agriculture and animal husbandry (aquaculture, irrigation systems, meadow and pasture 
breeding, forage crops raising, dairy cattle breeding, forage production, increasing productivity, fruit raising, raising awareness of farmers), hand arts education, environment and tourism education, information and technology education, health investments, drinking water and sewage infrastructure projects, education and health investments, struggle with animal-to-human diseases education, elderly patient and disabled care education, family planning and reproductive health education. The projects that are not included in the classification mainly include agriculture, industrial capacity development projects, tourism infrastructure projects and park projects. Within the scope of human development index, 62 projects were carried out by public institutions, 45 projects by non-governmental organizations, 5 projects by companies (SMEs) and 10 projects by farmer groups.

Of the 58 cultural projects in the TRB2 region (6,764,709 \$), 50 are about cultural heritage (traditional gastronomy, tangible heritage, traditional products, handicrafts), five are about cultural industries (publishing and print media), and finally three are about cultural industries and cultural heritage (tangible heritage, publishing and print media) (see table 9). The percentage of traditional gastronomy projects in the cultural economy within the scope of cultural heritage is $28.55 \%$, the percentage of handicraft projects is $29.18 \%$, and the percentage of publishing and print media projects within the cultural industries is $15.33 \%$. Accordingly, the most culturally-oriented projects in the region are in the class of cultural heritage and cultural industries. 32 of the 58 culture projects on TRB2 region basis belong to Van City only and received $3.816 .930 \$$ grant support. This amount of support constitutes $56.42 \%$ of the total cultural investments.

\begin{tabular}{|c|c|c|c|}
\hline \multicolumn{4}{|c|}{ EUROPEAN UNION PRE-ACCESSION FINANCIAL ASSISTANCE BETWEEN 2004-2009 MEDA TRB2 (VAN, BiTLIS, MUŞ, HAKKARI) } \\
\hline \multicolumn{2}{|l|}{ CULTURAL ECONOMY } & $\begin{array}{l}\text { NUMBER of } \\
\text { PROJECTS }\end{array}$ & PROJECT CONTENT \\
\hline CULTURAL HERITAGE (CH) & $\begin{array}{l}\text { Traditional gastronomy } \\
\text { Traditional Product } \\
\text { Historical, cultural and natural } \\
\text { heritage } \\
\text { Handicrafts }\end{array}$ & $\begin{array}{l}24 \\
2 \\
5 \\
19\end{array}$ & $\begin{array}{l}\text { Local Products (honey, walnut, wine grape } \\
\text { production, Norduz sheep, goat breeding for } \\
\text { buryan, pearl mullet) } \\
\text { Ahlat stone, travertine } \\
\text { Protected areas (historical-cultural-natural) } \\
\text { Rugs, wool and silk carpets, gold workmanship, } \\
\text { pottery making, walking sticks, wooden } \\
\text { handwork, walnut wood products }\end{array}$ \\
\hline \multicolumn{2}{|l|}{ TOTAL } & \multicolumn{2}{|l|}{50} \\
\hline CULTURE INDUSTRY (CI) & Publishing and print media & 5 & Books, guides (city and tourism), newspapers \\
\hline \multicolumn{2}{|l|}{ TOTAL } & 5 & \\
\hline $\begin{array}{l}\text { CULTURAL INDUSTRIES AND } \\
\text { CULTURAL HERITAGE }(\mathrm{Cl}+\mathrm{CH})\end{array}$ & $\begin{array}{l}\text { Historical, cultural and natural } \\
\text { heritage, publishing and print } \\
\text { media }\end{array}$ & 3 & Nature reserve, book, report \\
\hline \multicolumn{2}{|l|}{ TOTAL } & \multicolumn{2}{|l|}{3} \\
\hline GRAND TOTAL & 58 & & \\
\hline
\end{tabular}

Looking at the content of the projects, it is seen that the content is about; development and promotion of local products (honey, walnut, Norduz sheep, goat breeding for buryan, pearl mullet), restoration of nature conservation and historical areas, the development of environmental protection, development of handicrafts (rug workshops, gold and pottery work) short film, organizing festivals, publishing books, magazines, reports and guides (city and tourism guide).

Another striking point in this classification is that 16 of the 49 projects in the scope of the Tourism and Environment Grant Program covered cultural investments despite the title of tourism and environment. Accordingly, it is seen that investments in culture are supported in the tourism framework without creating a culture title in the EU MEDA Program. Accordingly, culture is associated with tourism.

Within the scope of MEDA program, the most support was provided to agricultural and rural development projects in TRB2 region. However, apart from the rural development policies of the region, it has been seen that the cultural and natural diversity has a significant tourism potential and the tourism sector has been supported as the second pillar of development. SME activities for employment and production diversity ranked third in priority support, followed by social development. Environmental funds for historical, natural and cultural heritage support the tourism sector. When the projects aimed at the development and production of handicrafts is evaluated within the framework of culture, it is seen that it is aimed to keep the local values alive and to increase the job opportunities.

The most important point of the MEDA Program is the amount and quality of the investments made in Van in the scale of TRB2 region. The MEDA Program, which is directly in line with the objectives of the Eastern Anatolia Project (DAP) 2000 Master Plan prepared in 2004-2009, has provided the most support to the city of Van in all its components and implemented the attraction center target determined in the plan (DAP, 2000). Also an important point is that before 
the establishment of Development Agencies in Turkey (Development Agencies were established in 2006, EADA was established in 2008), the EU has made investments under the MEDA Program, for the regional scale EADA limits (TRB2 / Van, Bitlis, Muş and Hakkari). Accordingly, it is seen that the EU is an international actor in the harmonization process and supports the regional policy understanding with investments.

\section{DISCUSSION AND CONCLUSIONS}

The SPO, which had a direct voice in development policies in Turkey and was considered one of the most important actors at the national level, underwent structural transformation following the policies aimed at articulating the global economy after 1980. Then the establishment of the Ministry of Development was realized, and it was seen as a turning point in the development approach. Especially between the years 1980-2000, in the process of effective international actors like the IMF and World Bank, neo-liberal economic policies began to be adopted and transition to a free market economy was set in motion in Turkey. This period also included the following: In 1999, Turkey's acceptance of candidacy for full EU membership in 2004, the Brussels Summit with the political criteria sufficient to give a positive opinion that welcomed Turkey and the EU affecting the development policies as the most influential of international actors with the start of full EU talks in 2005. Especially with the EU harmonization process, regional policies started to gain importance. Responsible for the planning and implementation of these policies at regional level, Development Agencies were established in 2006 and DAP Regional Development Administration in 2011. As a result of these changes, the holistic-national development approach has become a regional development approach. The central actors that shape development policies have been replaced by regional and local actors.

In Turkey, cultural policies in development policies have shifted from the emphasis on national culture to the emphasis on cultural diversity with the EU harmonization process. Culture has become important in economic and social dimensions. However, when we look at the development plans, it is not a direct target to develop the cultural field in the national and regional development approach. Development is mainly evaluated in the economic dimension. On the other hand, the components related to the cultural economy are handled within the framework of tourism and it is aimed to revitalize the tourism sector. Human development, on the other hand, has not been the priority, even though it has been included in the development goals. Accordingly, there is no clear human development target in the development approach. Regional development policies have also adopted a perspective that will mobilize, nurture and trigger the economic structure. In this direction, regional plans that give priority to the development of agriculture, industry and tourism sectors have been prepared. Culture, on the other hand, is considered as an investment area that feeds especially the agriculture and tourism sectors and has been instrumentalized for these sectors.

EADA, which is responsible for TRB2 region, supported projects aimed at industry, SME, tourism, growth centers/attraction centers and the natural and economic potentials of the cities in the region within the scope of TRB2 Regional Plans and supported the development of the capacities of public institutions.

The EU, which is one of the international actors, has provided support to structural and institutional arrangements, adaptation policies to socio-economic structure, R \& D studies and regional policies through financial support in Turkey with the help of the direction of development plans. Accordingly, the EU supported projects involving citizenship, human rights, cultural diversity, regional development, rural development, social development (participation of disadvantaged groups in social life), technological development, improvement of education opportunities, employment policies, and environmental policies.

In line with these changes in the planning and development approach at national and regional scale, the EU carries out the following activities in the support provided to the TRB2 Region and the city of Van: Development of sectoral development and growth centers within the scope of regional policies, promotion of human rights awareness, development of education opportunities, improvement of agricultural sector on the basis of rural development, increasing the participation of disadvantaged groups in social and economic life and giving priority to institutional capacity building for EU harmonization process. Within this framework, it can be stated that the EU gives priority to human rights, disadvantaged groups and policies for regional development in Van City.

The development problem of the TRB2 region is evidently seen in economic, social, human, and cultural dimensions. The EU and EADA have followed different policies in resolving this problem. By drawing attention to the local potential in regional development, the EU has supported investments that will bolster human and social capital. On the other hand, EADA has adopted a growth model covering different sectors. According to this growth model; Hakkari province is defined as "Mining and Logistics City", Muş province as "Agricultural Production and Agricultural Industry City", Bitlis province as "Tourism Focus and Museum City" and Van province as "Regional Central City Based on Commercial, Services and Industry Sectors". It can be seen in the research that $19.26 \%$ of EU grants and $35.90 \%$ of EADA supports 
evaluated as cultural economy investments in investments towards culture economy in TRB2 Region. It can be said that investments in the cultural economy of the TRB2 region, where there are regional inequalities and development problems abundant, may create a driving force in regional development. Based on the plans concerning the region, culture is associated with tourism as an economic structure and is considered significant in regional development.

The EU and EADA give priority to traditional gastronomy, crafts, and tangible heritage as cultural heritage. Within the scope of EU cultural industries, especially for publishing and print media, EADA emphasizes design and architecture in the context of creative services. While the EU emphasizes publishing and print media within the scope of cultural industries, EADA especially highlights design and architecture within the realm of creative services.

\section{References}

Accession Partnership Certificate. (2003). Accession Partnership for Turkey, State Planning Organization General Directorate for Relations with the European Union. Ankara.

Aksoy, A. \& Enlil, Z. (2011). Kültür Ekonomisi Envanteri. İstanbul: İstanbul Bilgi University Publications.

Andersson, A. (1985). Creativity and regional development. Papers in Regional Science, 56(1), 5-20.

Arslan, K. (2005). Bölgesel kalkınma farklılıklarının giderilmesinde etkin bir araç: bölgesel planlama ve bölgesel kalkınma ajansları. Istanbul Commerce University Journal of Social Sciences, 7, 275-294.

Baltacı, A. (2019). Nitel araştırma süreci: nitel bir araştırma nasıl yapılır?. Ahi Evran Üniversitesi Sosyal Bilimler Enstitüsü Dergisi (AEÜSBED), $5(2), 368-388$

Bengtsson, M. (2016). How to plan and perform a qualitative study using content analysis. NursingPlus Open, 2, 8-14. https://doi.org/10.1016/j.npls.2016.01.001.

Bianchini, F. (1993). Remaking European cities: the role of cultural policies. In F. Bianchini \& M. Parkinson (Eds.), Cultural policy and urban regeneration: the West European experience (pp. 21-57). Manchester UK: Manchester University Press.

Çalt, G. (2005). Bölgeselleşme ve Avrupa Birliği'nin bir araci olarak bölge kalkinma ajanslari. 6. Turkey agricultural engineering technical congress (3-7 January 2005). Notification Texts, Ankara.

Cooke, P. \& De Propris, L. (2011). A policy agenda for EU smart growth: the role of creative and cultural industries. Policy Studies, 32(4), 365375. https://doi.org/10.1080/01442872.2011.571852.

Crabtree, B. F. \& Miller, W. L. (1999). Doing Qualitative Research. Sage Publications.

Cunningham, S. D., Ryan, M. D., Keane, M. A. \& Ordonez, D. (2008). Financing creative industries in developing countries. In D. Barrowclough \& Z. Kozul Wright (Eds.), Creative industries and developing countries: voice, choice and economic growth (pp.65-110). London: Routledge.

DAP. (2000). The Eastern Anatolia Project (DAP) Master Plan. Prime Ministry State Planning Organization. Ankara.

DiNoto, M. \& Merk, L. (1993). Small economy estimates of the impact of the arts. Journal of Cultural Economics, 17(2), 41-53. https://doi.org/10.1007/BF02310581.

EADA. (2014). Eastern Anatolia Development Agency (EADA) 2014-2023 Period TRB2 Region Regional Plan. Retrieved December 18, 2015, from http://www.EADA.org.tr/panel/files/files/yayinlar/trb2_2014_2023_bp.pdf.

EADA. (2014a). Eastern Anatolia Development Agency Support Programs. Retrieved May 25, 2014, from http://www.EADA.org.tr/?cmd=page\&id=EADAdestekleri\#pagerO. 25 May 2014.

EADA. (2015). Vision 2023: Van City and Districts Vision 2023 Common Mind Strategic Action Plan. Retrieved December 18, 2015, from http://www.EADA.org.tr/panel/files/files/yayinlar/vizyon_2023_van_eylem.pdf.

EADAP. (2007). Eastern Anatolia Development Program Introduction Booklet.

EC, (2007). European Commission, the economy of culture in Europe. Retrieved September 19, 2015, from http://ec.europa.eu/assets/eac/culture/library/studies/cultural-economy_en.pdf.

EC. (2015). European Commission, first-ever European strategy for culture: contributing to economic growth and intercultural understanding. Retrieved September 19, 2015, from http://europa.eu/rapid/press-release_IP-07-646_en.htm.

Ekiz, C. \& Somel, A. (2007). Türkiye'de planlama ve planlama anlayışının değişimi. Mülkiye Dergisi, 31(256), 97-136.

Eşiyok, B. A. (2004). Türkiye Ekonomisinde Kalkınma Stratejileri ve Sanayileşme (Dün-Bugün-Yarın), Development Bank of Turkey Joint Stock Company, Research Directorate, ISBN 975-7406-40-6, Ankara.

Evans, G. \& Shaw, P. (2004). The contribution of culture to regeneration in the UK: a review of evidence, a report to the department for culture media and sport, London: LondonMet.. Retrieved May 8, 2013, from http://www.culture.gov.uk/images/consultations/ADCMS Final1.pdf.

Garcia, B. (2004). Cultural policy and urban regeneration in Western European cities: lessons from experience, prospects for the future. Local Economy, 19(4), 312-326. https://doi.org/10.1080/0269094042000286828.

Gordon, J. C. \& Beilby Orrin, H. (2007). International Measurement of the Economic and Social Importance of Culture, Organization for Economic Co-operation and Development (OECD).

Grodach, C. \& Seman, M. (2013). The cultural economy in recession: Examining the US experience. Cities, 33, 15-28. https://doi.org/10.1016/j.cities.2012.06.001.

Grodach, C. \& Silver, D. (2012). The Politics of Urban Cultural Policy: Global Perspectives. London and New York: Routledge.

Grodach, C. (2013). Cultural economy planning in creative cities: discourse and practice. International Journal of Urban and Regional Research, 37(5), 1747-1765. https://doi.org/10.1111/j.1468-2427.2012.01165.x.

Index Development Agency of Turkey, (2017). Turkey index map of development agencies. Retrieved June 28, 2017, from http://wowturkey.com/forum/viewtopic.php?t=114820. 
INTELI, (2011). Creative-based strategies in small and medium-sized cities: guidelines for local authorities. Retrieved May 8, 2013, from http://urbact.eu/sites/default/files/import/Projects/Creative_Clusters/documents_media/URBACTCreativeClusters_TAP_INTELI_Final _01.pdf.

Karataş, Z. (2015). Sosyal bilimlerde nitel araştirma yöntemleri. Sosyal Hizmet E-Dergi Manevi Temelli Sosyal Hizmet Araştırmaları Dergisi, $1(1), 62-80$.

Keser, H. Y. (2016). Culture economy for economic development: assessments on cultural heritage in Turkey. European Scientific Journal, 12(28), 38-50. http://dx.doi.org/10.19044/esj.2016.v12n28p38.

Kong, L. (2000). Culture, economy, policy: trends and developments. Geoforum, 31(4), 385-390. https://doi.org/10.1016/S00167185(00)00004-X.

Kumral, N. \& Güçlü, M. (2013). Kültür Ekonomisi ve Bölgesel Politika. Ege University Working Papers: Working Paper No: 13 /05.

Lazzeretti, L. (2013). Cultural and creative industries: an introduction. In L. Lazzeretti (Ed.), Creative industries and innovation in Europe ( pp. 1-20). London: Routledge.

Lazzeretti, L., Capone, F. \& Seçilmiş, İ. E. (2014). Türkiye'de yaratıcı ve kültürel sektörlerin yapısı. Maliye Dergisi, 166, 195-220.

Leadbeater, C. \& Oakley, K. (2001). Surfing the Long Wave: Knowledge Entrepreneurship in Britain. London: Demos.

Lucas, R. E. (1988). On the mechanics of economic development. Journal of Monetary Economics, 22, 3-42. https://doi.org/10.1016/03043932(88)90168-7.

Merriam, S. B. \& Grenier, R. S. (2019). Qualitative Research in Practice: Examples for Discussion and Analysis. San Francisco, CA: Jossey-Bass Publishers.

Ministry of Development. (2014). Ministry of development, national strategy for regional development. 2014-2023. Retrieved August 19, 2015,

http://www.kalkinma.gov.tr/Lists/EylemVeDigerPlanlar/Attachments/27/20142023\%20B\%C3\%B6lgesel\%20Geli\%C5\%9Fme\%20Ulus al\%20Stratejisi.pdf. 19 August 2015.

Mommaas, H. (2004). Cultural clusters and the post-industrial city: towards the remapping of urban cultural policy. Urban Studies, 41(3), 507-532. https://doi.org/10.1080/0042098042000178663.

Montgomery, J. (1996). Developing the media industries. Local Economy, 11(2), 158-168. https://doi.org/10.1080\%2F02690949608726322.

Mushkin, S. J. (1962). Health as an Investment. Journal of Political Economy, 70(5), Part 2, 129-157. https://doi.org/10.1086/258730.

Neuman, W. L. (2012). Toplumsal Araştırma Yöntemleri: Nicel ve Nitel Yaklaşımlar I-II. Cilt (5. Basım). İstanbul: Yayın Odası.

Oakley, K. (2004). Not so cool britannia. International Journal of Cultural Studies, 7(1), 67 -77. https://doi.org/10.1177/1367877904040606.

Official Gazette, (2006). Law No. 5449 on Establishment and Duties of Development Agencies, 8 February 2006 Issue: 26074.

ÖUKP. (2003). Preliminary National Development Program, 2004-2006. Ankara.

Potts, J. \& Cunningham, S. (2008). Four models of the creative industries. International Journal of Cultural Policy, 14(3), 233-247. https://doi.org/10.1080/10286630802281780.

Pratt, A. C. (1997). The cultural industries production system: a case study of employment change in Britain, 1984-91. Environment and Planning, 29, 1953-1974. https://doi.org/10.1068/a291953.

Republic of Turkey Ministry of Industry and Technology, (2019). Socio-economic development ranking survey of the provinces and regions SEGE-2017. Prepared by: Salih Acar, Mustafa Caner Meydan, Leyla Bilen Kazancık \& Mustafa Işık, Ankara. Directorate General of Development Agencies, Publication Issue: 3, Research Report Issue: 3, December 2019. Retrieved April 1, 2021, from https://www.sanayi.gov.tr/bolgesel-kalkinma-faaliyetleri/analitik-cal\%C4\%B1smalar/01123b.

Sab, R. S. \& Smith S (2001). Human Capital: International Evidence. IMF Working Paper, 32, 1-33.

Savrul, B. K. (2012). Türkiye-Avrupa Birliği mali işbirliği kapsamında bölgesel kalkınma programlarının etkinliği. istanbul Üniversitesi iktisat Fakültesi Mecmuası , 62(2), 355-371.

Schultz T. W. (1968). Education and Economic Growth: Return to Education, Readings in the Economics of Education, UNESCO, France.

Scott, A. J. (2006). Creative cities: conceptual issues and policy questions. Journal of Urban Affairs, 28(1), 1-17. https://doi.org/10.1111/j.0735-2166.2006.00256.x.

Strauss, A. \& Corbin, J. (1990). Basics of Qualitative Research: Grounded Theory Procedures and Techniques. Sage Publications.

Taş, B. (2006). AB uyum sürecinde Türkiye için yeni bir bölge kavramı: istatistiki bölge birimleri sınıflandırması (iBBS). Afyon Kocatepe University Journal of Institute of Social Sciences, 8(2), 185-197.

Tüik. (2021). Turkish Statistical Institute, Regional statistics. Retrieved March 25, 2021, from https://biruni.tuik.gov.tr/bolgeselistatistik/tabloOlustur.do\#.

UNCTAD. (2008). Creative economy report 2008. Retrieved March 25, 2021, from http://unctad.org/en/docs/ditc 20082cer_en.pdf.

UNDP. (2015). United Nations Development Program (UNDP). Humana Development Report, Abstract.

United Nations. (2010). Creative economy: a feasible development Option. Retrieved May 8, 2013, from http://www.undp.org.tr/publicationsdocuments/cer2010.pdf.

Yardımcıoğlu, M., Kocamaz, H. \& Sezal, N. (2012). Türkiye'de günümüze kadar izlenen bölgesel kalkinma politikalari ve kalkinma. 2. Regional issues and Turkey symposium (1-2 October 2012). Kahramanmaraş.

Yılmaz, A. (2012). Türkiye'de planlama politikası ve yönetimi planlamanın siyasal iktisadi ve yönetsel kuruluşu. (PhD Thesis, Ankara University, Institute of Social Sciences, Ankara). Retrieved from https://tez.yok.gov.tr/UlusalTezMerkezi/tezSorguSonucYeni.jsp.

Zukin, S. (1996). The Cultures of Cities. Cambridge. MA: Blackwell Publishers. 